\title{
Temporal variation in macroalgal removal: insights from an impacted equatorial coral reef system
}

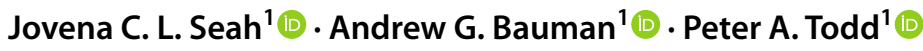

Received: 17 August 2020 / Accepted: 10 November 2020 / Published online: 4 January 2021

(c) The Author(s) 2020

\begin{abstract}
Macroalgal removal is a critical ecosystem function yet few studies have considered its temporal variability, especially on impacted reefs with limited herbivorous fish biodiversity. To address this, we quantified macroalgal removal and massstandardised bite rates of herbivorous fishes monthly from July 2016 to June 2017 using a series of transplanted Sargassum ilicifolium assays and underwater video cameras on three degraded coral reefs in Singapore: Pulau Satumu, Kusu Island, and Terumbu Pempang Tengah. Our results revealed a distinct temporal pattern in macroalgal herbivory (proportion of biomass removed and mass-standardised bite rates) rates across all sites, increasing from July and decreasing from January, with the highest rates recorded in December $\left(28.10 \pm 3.05 \mathrm{~g} 3.5 \mathrm{~h}^{-1} ; 208.24 \pm 29.99\right.$ mass-standardised bites $\left.3.5 \mathrm{~h}^{-1}\right)$ and the lowest in May $\left(0.86 \pm 0.17 \mathrm{~g} 3.5 \mathrm{~h}^{-1} ; 9.55 \pm 3.19\right.$ mass-standardised bites $\left.3.5 \mathrm{~h}^{-1}\right)$. These coincided with the $S$. ilicifolium growth cycle, confirming previous evidence that herbivory rates are closely linked to macroalgal condition. Video analyses revealed nine species feeding over a year (31,839 bites; 8702.89 mass-standardised bites), with Siganus virgatus responsible for $80 \%$ of the total mass-standardised bites. Siganus virgatus took the largest proportion of bites monthly, except between April and June, when Scarus rivulatus was dominant, suggesting temporal constraints in functional roles.
\end{abstract}

\section{Introduction}

Coral reefs are among the most productive and biologically diverse habitats on Earth (Spalding et al. 2001), providing important ecosystem goods and services to millions of people (Moberg and Folke 1999; Woodhead et al. 2019). Yet, coral reefs are also degrading rapidly in response to multiple local anthropogenic stressors (e.g. overfishing, sedimentation and pollution) that are compounded by the effects of

Responsible Editor: A. Gori.

Reviewed by J.-C. Daika and R. Streit.

Electronic supplementary material The online version of this article (https://doi.org/10.1007/s00227-020-03806-7) contains supplementary material, which is available to authorized users.

Peter A. Todd

dbspat@nus.edu.sg

Jovena C. L. Seah

jovenaseah@u.nus.edu

1 Experimental Marine Ecology Laboratory, Department of Biological Sciences, National University of Singapore, 14 Science Drive 4, Singapore 117558, Singapore climate change (Hughes et al. 2018). As coral reefs are set to undergo biodiversity losses and the functional extinction of species (Barlow et al. 2018), the ability of reefs to recover from threats is being reduced (Hughes et al. 2010), bringing about possible regime shifts from corals to macroalgae (Graham et al. 2015). This raises an urgent need to understand the nature of key ecosystem functions, especially herbivory by reef fishes, as this is regarded as critical to controlling macroalgae (Bellwood et al. 2004; Graham et al. 2013).

Intense feeding by herbivorous fishes moderate coralmacroalgal interactions by removing algae cover and/or biomass that compete with corals for space (Diaz-Pulido and McCook 2003; Hughes et al. 2007). Because this process influences reef resilience, it is one of the most widely quantified ecological functions on coral reefs-measured by realised (algal mass lost) or estimated (rate of feeding) metrics (e.g. Fox and Bellwood 2008; Hoey and Bellwood 2011; Plass-Johnson et al. 2015; Loffler et al. 2018). Previous studies on macroalgae removal have furthered our understanding of the key species involved (see review Puk et al. 2016) and expounded on concepts of functional complementarity and redundancy (e.g. Bellwood et al. 2004; Hoey and Bellwood 2009; Hughes et al. 2005). Most studies have compared this function across various spatial scales, e.g. locally (Fox and 
Bellwood 2007; Cvitanovic and Bellwood 2009), along the continental shelf (Hoey and Bellwood 2010), among latitudes (Bennett and Bellwood 2011), and even a cross-system comparison spanning biogeographical regions (Tebbett et al. 2020). However, the majority of these studies are generally single, one-off experiments conducted over a few weeks or months when macroalgal condition is ideal for feeding assay trials (Puk et al. 2016; Topor et al. 2019). Consequently, we lack a comprehensive understanding of this critical ecosystem function over longer temporal scales (but see Lefèvre and Bellwood 2011) and how this may affect coral communities over time.

Despite the large body of research, how herbivory rates change with time remains poorly understood, especially in marginal and degraded reef systems. Lefèvre and Bellwood (2011) identified temporal variability in macroalgal herbivory rates on inshore reefs of the Great Barrier Reef (GBR) and proposed that changes in Sargassum size and condition was a major influencing factor. The coral reefs of Singapore represent a heavily impacted system, having experienced stressors associated with massive development since the 1960s (Lai et al. 2015; Poquita-Du et al. 2019; Heery et al. 2018). Reefs in this small city-state support reduced diversity and abundance of herbivorous fish species, yet they retain the ecosystem function of macroalgal removal (Bauman et al. 2017), and coral dominance has persisted (Guest et al. 2016). However, no temporal studies comparing rates of macroalgae removal have been conducted on Singapore's reefs, limiting our ability to understand how this ecological function is maintained.

Coral reefs in Singapore provide a unique opportunity for examining temporal variation in the functional role of macroalgal removers within a highly disturbed, urbanized reef environment with low fish diversity (Bauman et al. 2017; Taira et al. 2018). Leveraging this opportunity, the objective of our study was to quantify how fish herbivory of macroalgae varied over time within Singapore's reefs using a combination of transplanted macroalgal assays and remote underwater video cameras. We measured both realised (macroalgae biomass removed) and estimated (mass-standardised bite rates) herbivory rates for one year, and investigated whether temporal changes in macroalgal removal were associated with macroalgal condition and/or particular herbivorous fish species.

\section{Material and methods}

\section{Study area}

This study was conducted for one year between July 2016 and June 2017 in three offshore shallow coral reefs (Terumbu Pempang Tengah, Pulau Satumu and Kusu Island) of the southern coastline of Singapore Island (Fig. 1). All three reefs are characterized by a reef flat leading seaward to the reef slope where coral communities descend to $\sim 8 \mathrm{~m}$ depth (Guest et al. 2016). The depth restriction is primarily due to extreme light attenuation from chronic sedimentation and suspended particles (Chow et al. 2019). These three reefs were selected because they have the highest coral cover, lowest macroalgal cover, and highest rates of macroalgal removal in Singapore (Bauman et al. 2017). At each reef, we quantified herbivorous fish assemblages and rates of macroalgal removal monthly on the upper reef slope (3-4 m
Fig. 1 Map showing four reefs in the Southern Islands of Singapore. S. ilicifolium assays were collected from Pulau Hantu and transplanted onto Kusu Island, Pulau Satumu and Terumbu Pempang Tengah

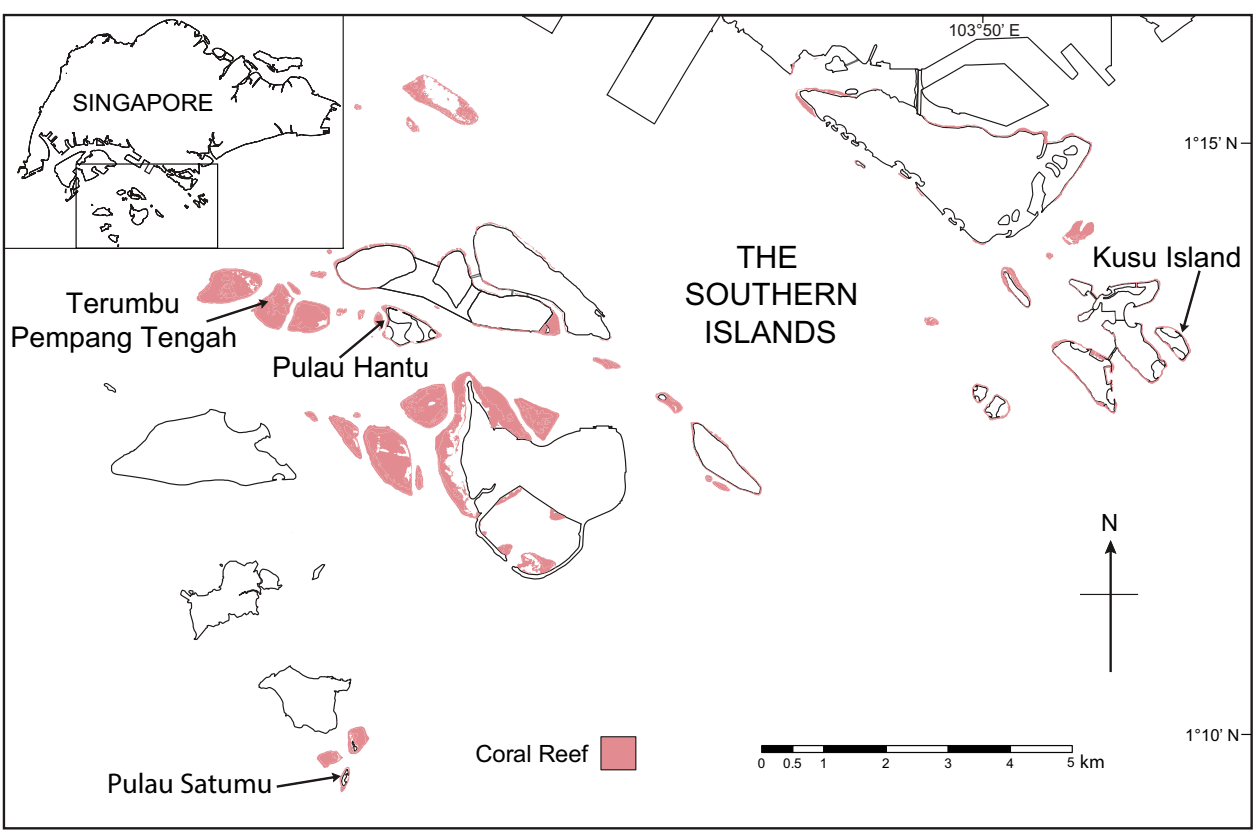


depth), i.e. the area of greatest herbivore activity (Bauman et al. 2017).

\section{Herbivorous fish surveys}

To evaluate monthly variation in the relative abundances and biomass of roving herbivorous fishes among reefs, all nominally herbivorous fishes (i.e. Acanthuridae, Kyphosidae, Pomacanthidae, Labridae, Siganidae; ESM, Table S1) were visually surveyed using a series of timed swims. Three surveys were conducted along the upper reef slope within each reef with adjacent swims spaced $10 \mathrm{~m}$ apart and encompassed the areas where the macroalgal removal experiments were conducted (see details below). Each survey consisted of a diver (always AGB) swimming parallel to the upper reef slope for $5 \mathrm{~min}$ and recording all nominally herbivorous fishes greater than $10 \mathrm{~cm}$ total length (TL) within a $5 \mathrm{~m}$ wide transect that extended from the reef substratum to the surface of the water. Individual fishes were identified to species and their total length was estimated into $5 \mathrm{~cm}$ size categories. Care was taken not to re-record fish that left and subsequently re-entered the survey area. Timed swims were selected due to generally poor diving conditions in Singapore (visibility $<3 \mathrm{~m}$ ) and to increase the likelihood of detecting larger roving species. The number of fish per unit effort were converted to densities per unit area by estimating the length of each transect ( $\sim 60 \mathrm{~m}$, following Bellwood and Wainwright 2001). Density estimates were later converted to biomass $\left(\mathrm{kg} 300 \mathrm{~m}^{-2}\right)$ using published species length-weight relationships (Kulbicki et al. 2005; Hoey et al. 2013). All surveys were conducted between 10:00 and 12:00 $\mathrm{h}$ on days that macroalgal removal experiments were not being conducted within those reefs.

\section{Macroalgal removal and herbivore feeding}

To quantify monthly variation in macroalgal removal rates among reefs, we transplanted a series of Sargassum ilicifolium assays along the upper reef slope at each reef over three non-consecutive days each month. Sargassum ilicifolium was selected because it is the most abundant Sargassum species in Singapore (Low et al. 2019) and is known to be consumed by herbivorous reefs fishes in Singapore (Bauman et al. 2017, 2019). Sargassum ilicifolium thalli of similar heights $(\mathrm{ca} .40 \mathrm{~cm})$ were collected from the reef flats around Pulau Hantu each deployment day (Fig. 1). Thalli were spun in a salad spinner for $\sim 20 \mathrm{~s}$ to remove excess water, and the wet weight recorded to the nearest $0.1 \mathrm{~g}$ (Table S2). Four haphazardly selected assays were subsequently transplanted to the upper reef slope on each reef, over three non-consecutive days. Each S. ilicifolium assay was attached directly to the reef with a rubber band and short $(<10 \mathrm{~cm})$ length of galvanized wire $(0.5 \mathrm{~mm}$ diameter) wrapped around the thallus holdfast and secured to the substratum with a galvanized nail. One assay was placed inside a cylindrical exclusion cage (15 cm radius, $100 \mathrm{~cm}$ height, $0.5 \mathrm{~cm}$ mesh) to control for any loss of biomass due to handling. Small plastic tags were placed adjacent to each assay to identify individual thalli. All assays were separated from adjacent assays by a minimum of $10 \mathrm{~m}$ and were deployed between 09:00 and 11:00 and retrieved after $4.0 \mathrm{~h}$. Following retrieval, each assay was spun and re-weighed as described above.

To identify herbivorous fish species removing $S$. ilicifolium biomass, small stationary underwater video cameras (GoPro Hero Silver $3+$ ) recorded feeding activity on one haphazardly selected assay at each reef each day. Each camera was mounted to a $2 \mathrm{~kg}$ dive weight and positioned approximately $1 \mathrm{~m}$ away from each assay, with a $10 \mathrm{~cm}$ scale bar placed adjacent to one assay for approximately $10 \mathrm{~s}$ to allow calibration of fish sizes on the video. Filming commenced immediately after all assays were attached to the reef and was continuous for $\sim 4 \mathrm{~h}$. This procedure was replicated on three non-consecutive days on each reef each month resulting in $12 \mathrm{~h}$ of video observations per month for each reef ( $144 \mathrm{~h}$ in total).

The first $20 \mathrm{~min}$ and the last $10 \mathrm{~min}$ of each video was discarded to minimize potential diver interference. From the remaining $3.5 \mathrm{~h}$ of footage, the total number of bites taken by each species and body size (TL) were recorded. To account for variation in fish body size on S. ilicifolium biomass removed, the total number of bites per fish species was converted to mass-standardised bites as a product of estimated body mass and total number of bites for each individual using published length-weight relationships (following Hoey and Bellwood 2009).

\section{Data analysis}

Temporal variation in total biomass $\left(\mathrm{kg} 300 \mathrm{~m}^{-2}\right)$ and abundance (individuals $300 \mathrm{~m}^{-2}$ ) of all herbivorous fishes, and variation in S. ilicifolium removal rates (percentage biomass loss $4 \mathrm{~h}^{-1}$ ) were assessed with linear mixed-effect (LME) models with a Gaussian residual structure. Herbivorous fish feeding rates (mass-standardised bites $3.5 \mathrm{~h}^{-1}$ ) was assessed with generalised mixed-effect models (GLMMs). All mixed effect models included "month" as a fixed effect and "month" nested within "site" as a random effect to account for repeated surveys each month across sites.

To improve normality for the LME models, the total biomass and abundance of herbivorous fishes of each transect were square-root transformed. Similarly, after controlling for handling loss by subtracting the mean value of loss from the control (caged assays) for each experimental thallus (following Cronin and Hay 1996), the proportion loss of biomass from each assay was also square-root transformed to improve normality. To assess the effect of spatial variation (site), 
marginal and conditional $R^{2}$ of each model were computed. Model assumptions of homogeneity of variance and normality were validated by visual inspections of the residual plots for the LME models and DHARMa diagnostic plots for the GLMM. To examine within-level differences, pairwise means comparisons between months were made with Tukey adjustments of $p$-values. All statistical analyses were performed in the software R ( $\mathrm{R}$ Core Team 2020), using the nlme (Pinheiro et al. 2020), glmmTMB (Brooks et al. 2017), MuMIn (Barton 2020), DHARMa (Hartig 2020) and emmeans (Lenth 2020) packages.

\section{Results}

\section{Herbivore abundance and biomass}

A total of 3242 individual roving herbivorous fishes of nine different species within three families (Labridae,
Siganidae and Pomacanthidae) were recorded from all the timed swims combined (Table S1). Mean monthly biomass and abundance of roving herbivorous fishes ranged from $5.11 \pm 0.81 \mathrm{~kg} 300 \mathrm{~m}^{-2}$ and $25.33 \pm 3.89$ individuals

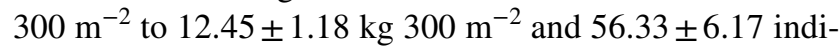
viduals $300 \mathrm{~m}^{-2}$ (Fig. 2; Table S3), and did not differ among sites across the year $(\mathrm{F}(11)=48.8, p=0.42$ and $\mathrm{F}(11)=48.8$, $p=0.27$ respectively). The addition of site as a random effect into the random intercept model captured $77.2 \%$ and $78.8 \%$ of the variance in fish biomass and abundance respectively, as compared to the fixed effect models that only captured 3.6-5.4\% respectively (Table S4). The mean abundance and biomass of herbivorous fishes was highest on Pulau Satumu, followed by Kusu Island, and lowest on Terumbu Pempang Tengah (Table S2). Scarus rivulatus was the most abundant roving herbivore among sites, with 1232 individuals accounting for $36.9 \%$ of the total abundance and $43.7 \%$ of the total biomass across months. Siganus virgatus and Siganus javus were the next most abundant herbivores a

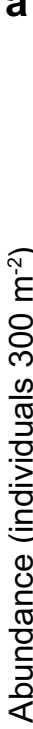

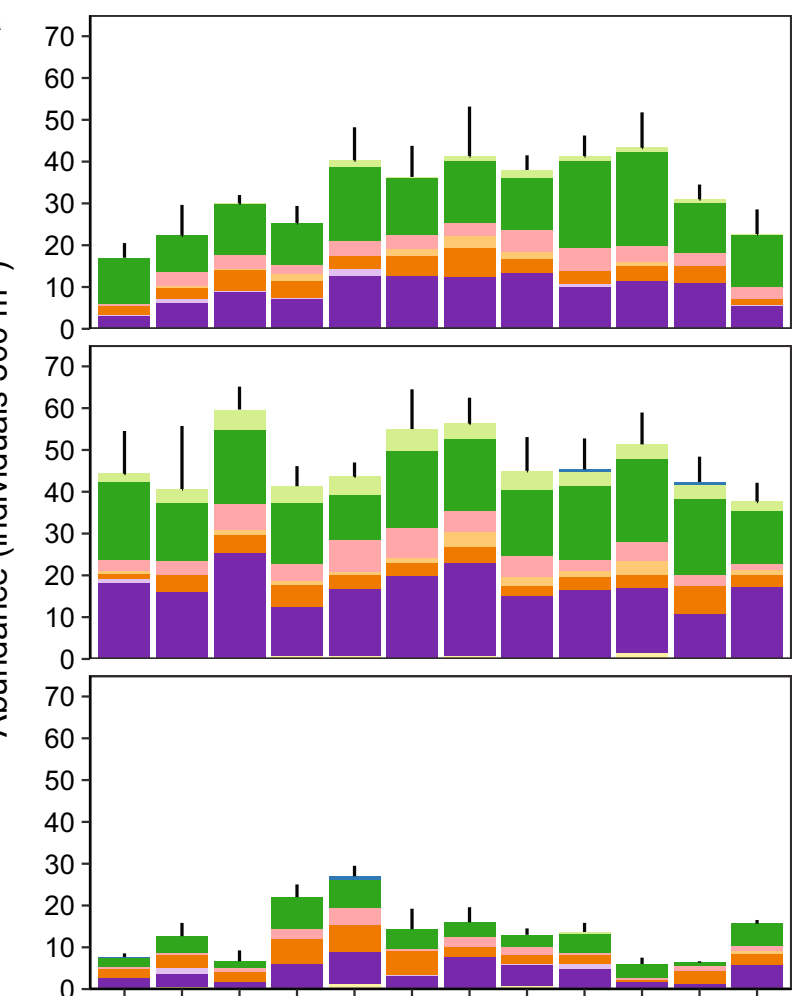

Jul Aug Sep Oct Nov Dec Jan Feb Mar Apr May Jun Month
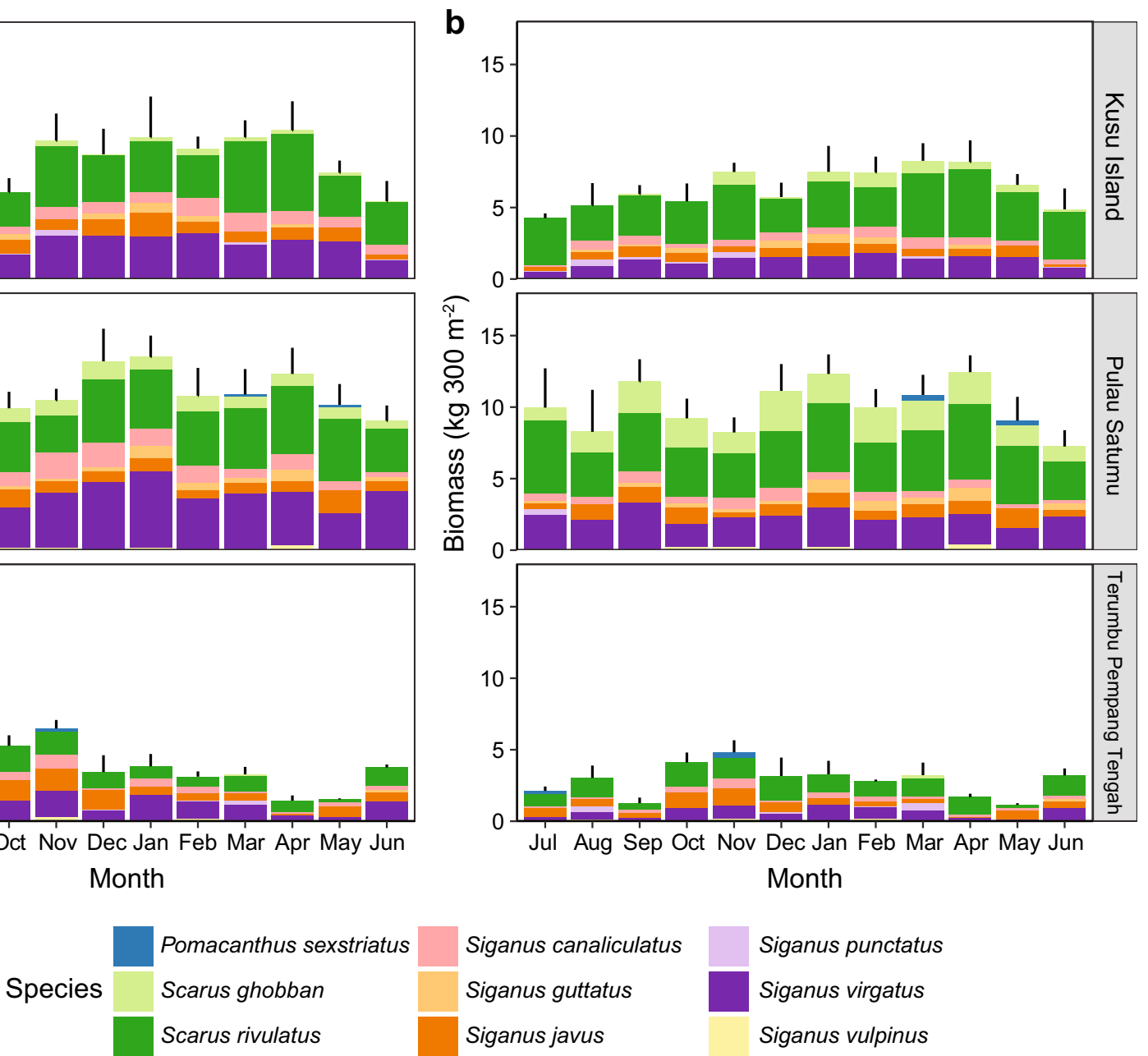

Siganus canaliculatus

Siganus guttatus

Siganus javus

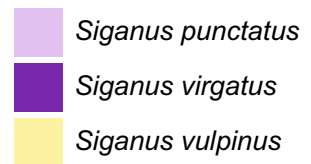

Fig. 2 Mean abundance (a) and biomass (b) of herbivorous fish species per $300 \mathrm{~m}^{-2}$ recorded during timed swims on Kusu Island, Palau Satumu, and Terumbu Pempang Tengah during one year 
among sites, with 1101 and 377 individuals for each species, and accounted for $21.5 \%$ and $10.3 \%$, respectively, of the total herbivore biomass (Table S1).

\section{Temporal macroalgal removal}

The removal of $S$. ilicifolium biomass varied significantly among months $(\mathrm{F}(11)=48.8, p<0.01)$, and also appeared to vary among sites, with the random intercept model including site as a random effect accounting for an additional $41 \%$ of the variance in removal rates (Table S4). Among sites, the removal rates of $S$. ilicifolium biomass ranged from $3.19 \pm 0.63 \%\left(0.86 \pm 0.17 \mathrm{~g}^{4} \mathrm{~h}^{-1}\right)$ to $34.66 \pm 3.82 \%$ $\left(28.10 \pm 3.05 \mathrm{~g} \mathrm{~h}^{-1}\right)$ and, throughout the year, were always highest on Pulau Satumu compared to both Kusu Island and
Terumbu Pempang Tengah (Fig. 3; Table S5). There was a clear pattern in mean removal rates of $S$. ilicifolium biomass with removal increasing from July and decreasing from January. The highest removal rates were recorded in December and January $(34.66 \pm 3.82$ and $30.67 \pm 3.19 \%)$ and the lowest removal rates were recorded in May and June $(3.19 \pm 0.63$ and $5.44 \pm 1.01 \%$; Fig. 3). Despite the significant differences in feeding rates across months, there was temporal consistency in rank order among sites in mean biomass removal (Pulau Satumu $>$ Kusu Island $>$ Terumbu Pempang Tengah) associated with similar rank order in herbivorous fish biomass among sites.
Fig. 3 Proportion of macroalgae biomass removed (a) and number of mass-standardised bites taken (b) at Kusu Island, Palau Satumu, and Terumbu Pempang Tengah from July 2016 to June 2017. Boxplot depict median and $25 \%$ quantiles, coloured circles are raw data points with outliers represented with a black dot, while diamonds are site means. Letters above indicate significant differences $(p<0.05)$

\section{a}

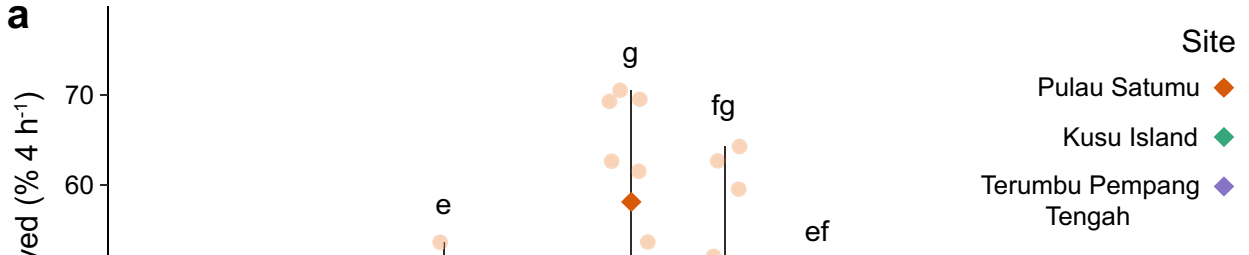

¿ุ 50
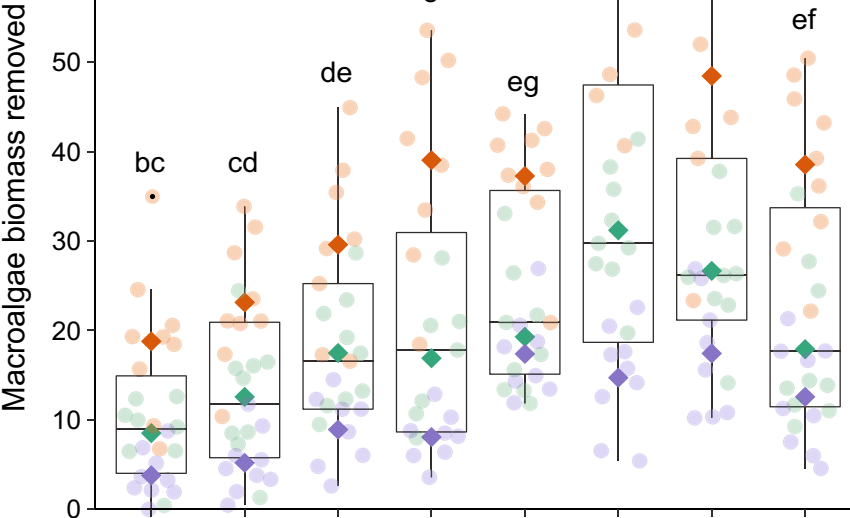

cd

b

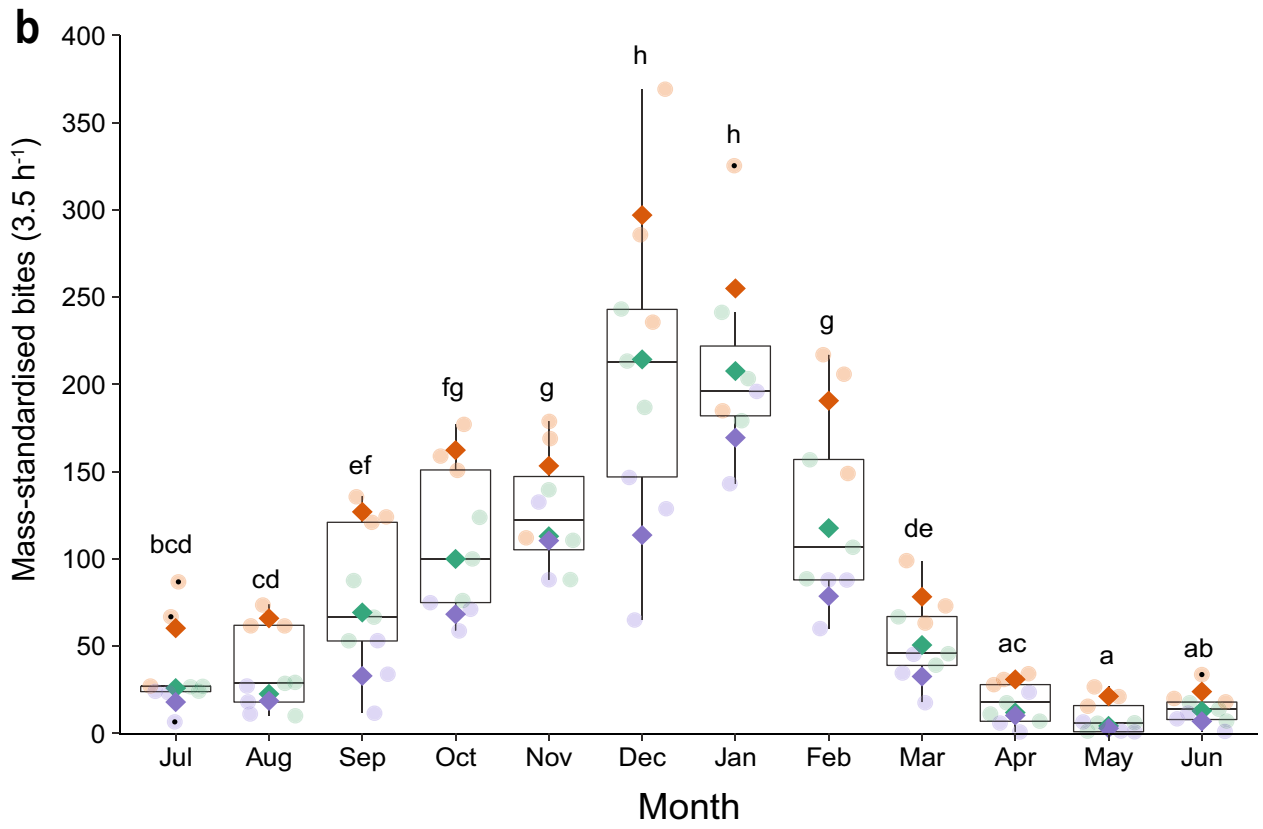




\section{Bite rates}

Analysis of video footage revealed a total of 31,839 bites (8702 mass-standardised bites) from nine fish species feeding on the S. ilicifolium assays from all reefs and months combined. Feeding rates on $S$. ilicifolium differed among months $\left(\chi^{2}=654.33, \mathrm{df}=11, p<0.01\right)$. An additional $11 \%$ of variance in bite rates was explained by the random intercept model that included site as a random effect (Table S4). Feeding rates ranged from $9.55 \pm 3.19$ mass-standardised bites $3.5 \mathrm{~h}^{-1}$ to $210.19 \pm 22.19$ mass-standardised bites $3.5 \mathrm{~h}^{-1}$ and were invariably higher on Pulau Satumu than Kusu Island and Terumbu Pempang Tengah (Fig. 3; Table S6), however, the difference in feeding rates between Kusu Island and Terumbu Pempang Tengah was less distinct, particularly in the low feeding months (July to August 2016 and April to June 2017). Temporal bite rate patterns were almost identical to rates of removal, with increases from July and decreases from December. Mean feeding rates were significantly higher in December and January $(208.24 \pm 29.99$ and $210.19 \pm 22.19$ mass-standardised bites $3.5 \mathrm{~h}^{-1}$ ) and lower in May and June $(9.55 \pm 3.19$ and $14.58 \pm 3.13$ mass-standardised bites $3.5 \mathrm{~h}^{-1}$ ) (Table S6).

Mass-standardised bites were taken by roving herbivorous fishes from nine species within five families: Kyphosidae (Kyphosus vaigiensis), Siganidae (Siganus corallinus, $S$. canaliculatus, S. javus, S. punctatus, S. virgatus), Labridae (Scarus ghobban, S. rivulatus), and Pomacanthidae (Pomacanthus sexstriatus). Of the nine herbivorous fishes, $K$. vaigiensis and $S$. corallinus were recorded feeding but not observed in the fish surveys (Figs. 2, 4). Site-specific feeding activity was found for S. ghobban (only Pulau Satumu), $S$. punctatus (only Terumbu Pempang Tengah), P. sexstriatus (only Terumbu Pempang Tengah), and $K$. vaigiensis (except Terumbu Pempang Tengah) (Fig. 4).

A single species $S$. virgatus, was responsible for $\sim 80 \%$ (6,959 mass-standardised bites) of the mass-standardised bites taken across Sargassum assays throughout the year while $K$. vaigiensis, S. rivulatus, and $S$. javus, accounted for the majority of the remaining mass-standardised bites (18\%; 1,509 mass-standardised bites) (Table S7; Fig. 4). There was a clear temporal pattern in the monthly proportion of bites taken, with $S$. virgatus feeding the most throughout the year until April, May, and June, when the main herbivore switched to $S$. rivulatus. At Terumbu Pempang Tengah, where $K$. vaigiensis did not feed, both the total mass-standardised bites and the monthly proportion of bites taken by S. javus was higher than at the other two sites (Figs. 4, 5).

\section{Discussion}

Macroalgal removal by herbivorous fishes is one of the most widely quantified ecological processes on coral reefs, yet we lack a comprehensive understanding of this critical function over longer temporal scales (Puk et al. 2016; Topor et al. 2019). Monthly macroalgal removal rates from the three reefs in Singapore showed a high degree of temporal variation consistent with patterns reported from other inshore reefs systems (Lefèvre and Bellwood 2010, 2011). Overall, mean monthly removal rates of $S$. ilicifolium assays and total bites by herbivorous fishes was low (3-35\% removal and 31,839 total bites) compared to inshore reef studies using similar methods (15-90\% removal and 111,798 total bites, Lefèvre and Bellwood 2011). Rates of removal were highest in December $\left(7.02 \mathrm{~g} \mathrm{~h}^{-1}, 28.1 \% \pm 3.1\right)$ and lowest in May $\left(0.86 \mathrm{~g} \mathrm{~h}^{-1}, 3.2 \% \pm 0.6\right)$ with a relatively consistent pattern of increasing removal rates from July to December and decreasing removal rates from January to June. A single species, S. virgatus, was responsible for the majority of feeding most of the year (i.e. July to March), and accounted for $80.0 \%$ of mass-standardised bites on S. ilicifolium assays. Importantly, results revealed that the essential ecosystem process of macroalgal removal (the 'realized function' sensu Bellwood et al. 2019) appears to be maintained throughout the year on these heavily impacted reefs despite limited diversity and low abundances of herbivorous fishes (Bauman et al. 2017).

Temporal variation in macroalgal removal from reefs in Singapore is likely due to seasonal differences in S. ilicifolium assay biomass and changes in herbivorous fish feeding patterns. Our results showed a direct relationship between S. ilicifolium assay biomass and proportion of macroalgae removed, with macroalgal removal rates 9- to 22-fold higher in December during the peak growth cycle of S. ilicifolium than at the end of the growth cycle in May. Previous macroalgal removal studies report similar temporal patterns of variable removal rates associated with annual Sargassum growth cycles. For example, a temporal removal study on the GBR revealed strong seasonal variation in the removal of Sargassum between the summer and winter (Lefèvre and Bellwood 2011) associated with the annual growth cycle. In Singapore, the annual growth cycle $S$. ilicifolium generally commences in June or July with peak growth culminating in December or January. This is followed by the onset of senescence which generally starts in January or February and ends in May (Low et al. 2019). The annual growth cycle coincided with the increases (July to December; June), and decreases (January to May) in macroalgal herbivory rates, supporting the notion that temporal macroalgal removal patterns is closely associated with the Sargassum growth cycle and potential changes in condition. Despite an increase in 
Fig. 4 The number of massstandardised bites taken by nominally herbivorous fishes at Kusu Island, Pulau Satumu, and Terumbu Pempang Tengah from July 2016 to June 2017
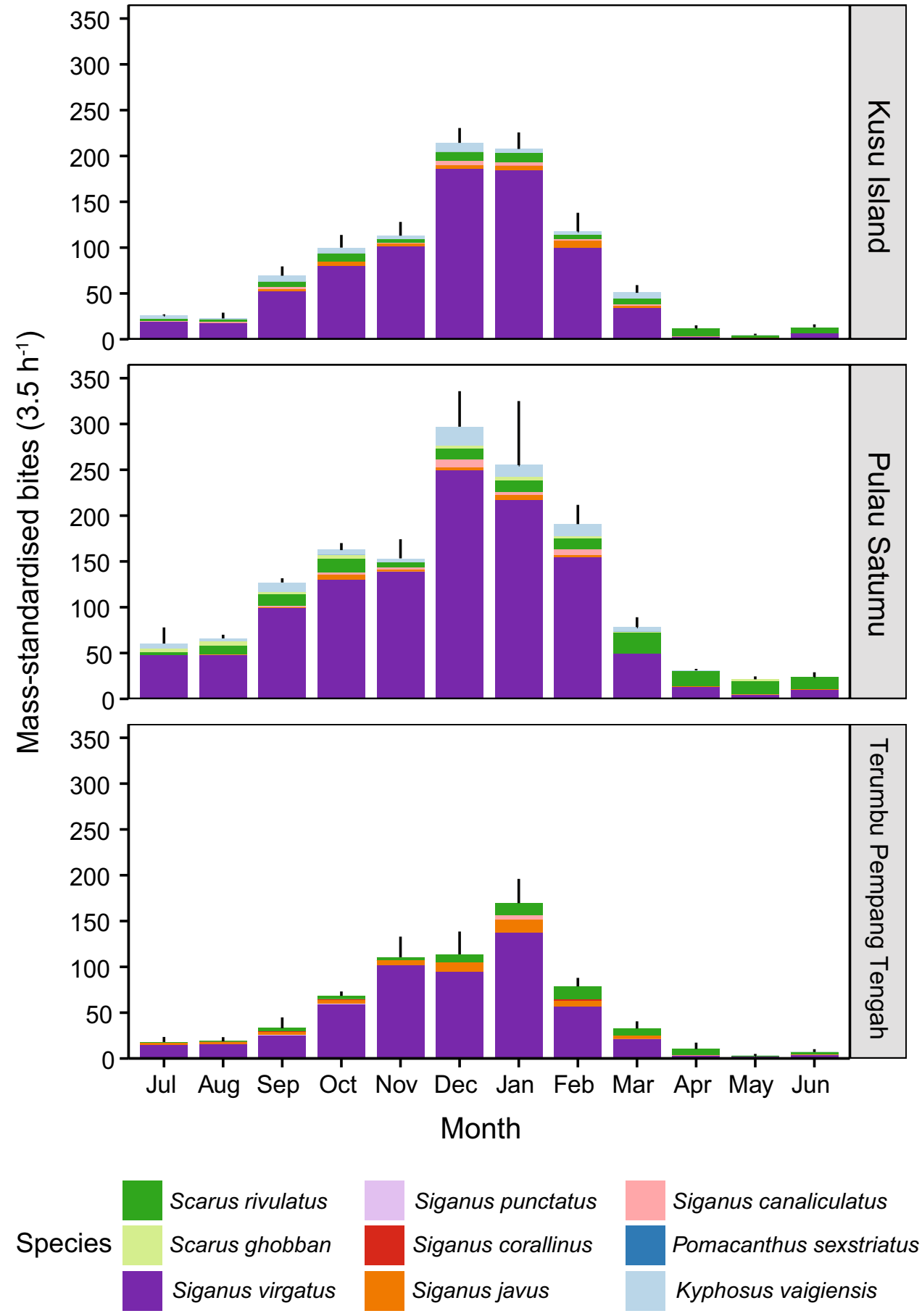

assay biomass in January, herbivory rates started to decrease, likely triggered by the onset of Sargassum condition deteriorating, further indicating that changes in macroalgal herbivory rates are not solely due to the amount of Sargassum available.

Of the nine species recorded feeding on the macroalgal assays, five are recognized macroalgal removers ( $S$. virgatus, S. canaliculatus, S. javus, K. vaigiensis and Pomacanthus sexstriatus, Puk et al. 2016), and all but P. sexstriatus have been recorded feeding on Sargassum in Singapore (Bauman et al. 2017, 2019). Consistent with previous findings, S. virgatus appeared to be the most functionally important macroalgal remover across reefs in Singapore (Bauman et al. 2017, 2019). Notably, S. virgatus was responsible for the majority of mass-standardised bites for nine consecutive months from July to March followed by a pronounced decrease in feeding intensity between April and June. This finding differs from species that have been shown to dominate on 

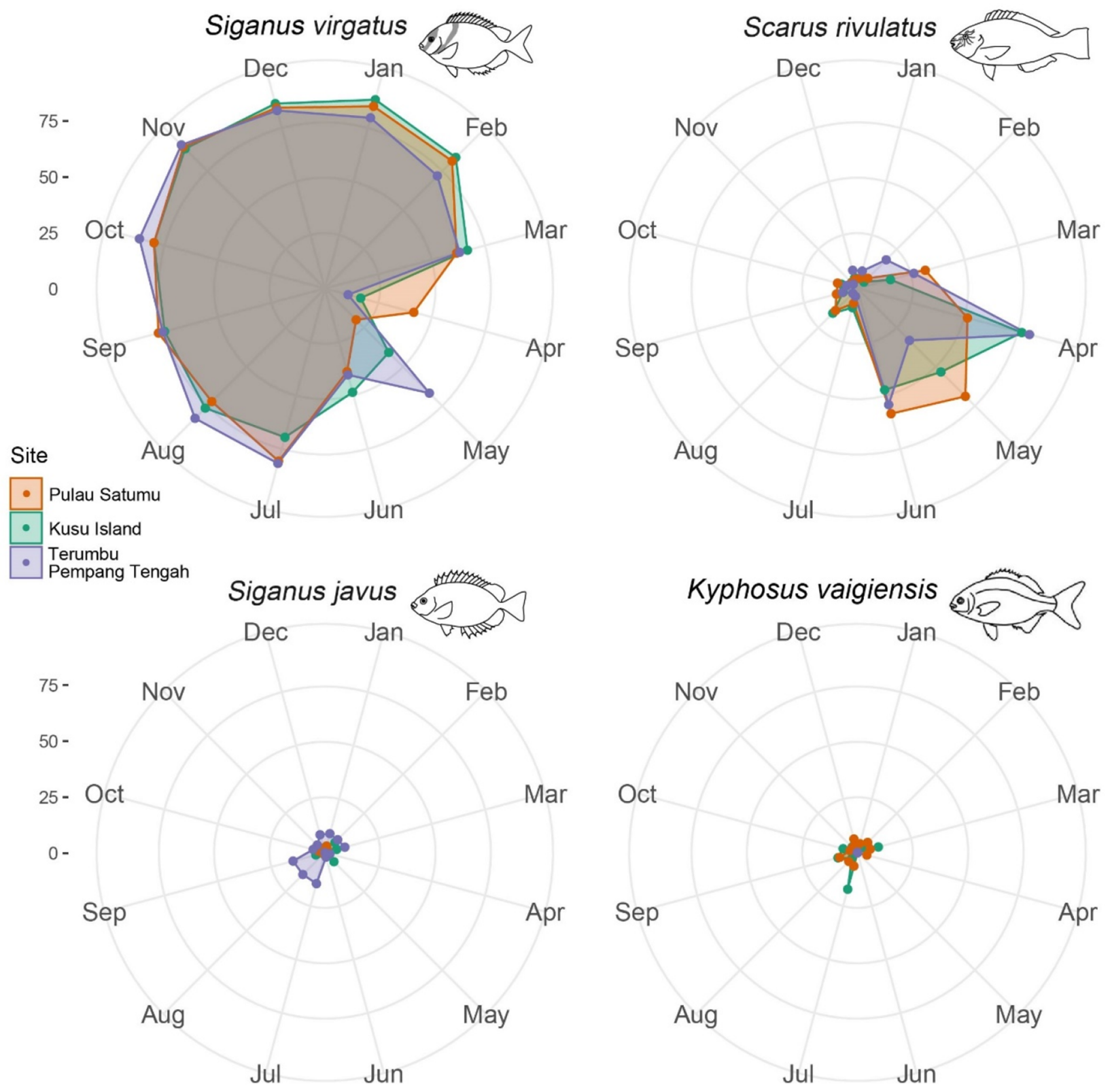

Our study found that the temporal variation in macroalgal removal and species feeding dominance on coral reefs in Singapore is best explained by changes in macroalgal condition, while spatial variation is best explained by differences in local herbivore biomasses.

Fig. 5 Proportion of mass-standardised bites per month at each site for the four herbivorous fishes that contributed the most to biomass removal

the GBR such as K. vaigiensis or Naso unicornis (Hoey and Bellwood 2009; Lefèvre and Bellwood 2011; PlassJohnson et al. 2015), suggesting that macroalgal removal is largely dependent on site-specific fish diversity (Bauman et al. 2017). Secondly, temporal differences in macroalgal removal rates varied among species, with peak feeding rates of $S$. rivulatus occurring slightly later than other species $(S$. virgatus, S. javus, and K. vaigiensis), or increasing (April to June) while herbivory rates of the rest decreased. Although the increase in macroalgal removal by $S$. rivulatus was less pronounced as the increase in removal rates by $S$. virgatus, the slightly later peak feeding rates implies a switch in the 
dominant macroalgal remover from S. virgatus to $S$. rivulatus between April and June.

As there were no overall differences in fish biomasses during the year, to understand the temporal variation in herbivory rates it is necessary to examine the effects of the growth cycle of $S$. ilicifolium on the feeding behaviours of the different herbivorous fishes. Siganus virgatus is potentially a 'mixed feeder' that consumes both macroalgae and epilithic algal matrix (EAM) (Nanami 2018), and typically only target Sargassum leaves (Streit et al. 2015). When Sargassum blades undergo necrosis, become colonised by epiphytes during senescence (McCook 1997), and are shed (e.g. Rivera and Scrosati 2006; Lefèvre and Bellwood 2010), it is possible that some rabbitfishes may switch from feeding on brown leathery macroalgae (e.g. Sargassum) to feeding on EAM (Hoey et al. 2013). Kyphosus vaigiensis has been posited to respond to the condition of algae (Lefèvre and Bellwood 2011) and height of assays (Hoey 2010). As assay lengths were kept constant in the present study, a plausible reason for the decrease and cessation of feeding, as with the siganids, is Sargassum condition. In contrast, the parrotfish, $S$. rivulatus, is a microphage that feeds on microscopic autotrophs epiphytic on macroalgae (Clements et al. 2017). The period of senescence thus provides more food resources for these species to exploit. While S. rivulatus may not be directly targeting Sargassum, they likely remove macroalgae when feeding on epiphytes growing on the Sargassum. The differing response of these species to the condition of algae could explain why rates of herbivory varied among species, especially from January onwards when senescence commences, and why there was a switch in the dominant macroalgae remover from $S$. virgatus to $S$. rivulatus between April and June.

Aside from the apparent temporal patterns, the results also indicate spatial differences in the removal of S. ilicifolium biomass. Month-on-month throughout the year there was greater macroalgal removal on Pulau Satumu compared to Kusu Island and Terumbu Pempang Tengah (Fig. 3). Herbivorous fish biomass was also consistently higher on Pulau Satumu compared to both Kusu Island and Terumbu Pempang Tengah throughout the year. Contrary to the studies on the GBR that have shown herbivore biomass is a poor predictor of herbivory rates (Hoey and Bellwood 2009; Cvitanovic and Bellwood 2009; Richardson et al. 2020), it appears that on degraded reefs such as those found in Singapore, where species richness and abundances are low (Bauman et al. 2017), that even slight differences $(\sim \pm 5 \mathrm{~kg}$ $300 \mathrm{~m}^{-2}$ ) in herbivorous fish biomass may influence herbivory rates. As the process of macroalgal herbivory was largely reliant on $S$. virgatus, the loss of this species could lead to increased macroalgal growth. However, our results also suggest that other herbivorous fishes may negate, to some degree, any herbivory deficit caused by the absence of a particular species. For example, we observed that $S$. javus seemingly makes up for possible herbivory reduction caused by the absence of $K$. vaigiensis at Terumbu Pempang Tengah. We found the highest feeding rates among the three sites for $S$. javus, as well as mostly higher percentage contribution to bites in Terumbu Pempang Tengah compared to Kusu Island or Pulau Satumu. S. javus biomass in Terumbu Pempang Tengah was similar to Kusu Island and less then Pulau Satumu, indicating some capacity to offset lower species richness. This has important implications for coral reef resilience, although caution should be used if relating this finding to the loss of the functionally dominant species ( $S$. virgatus).

Patterns of temporal macroalgae removal in Singapore were similar to those reported from the GBR (Lefèvre and Bellwood 2011), but rates were considerably lower due to reduced fish densities. The low abundance and diversity of herbivorous fishes is unlikely a result of high fishing pressure as commercial fishing is prohibited (Wong and Chou 2004) and populations have had over 50 years to recover from the effects of historical fishing. However, the reefs in Singapore are degraded, impacted in particular by high levels of sedimentation, nutrients, and turbidity (Guest et al. 2008; Browne et al. 2014; Junjie et al. 2014), and this could be influencing fish numbers and diversity (Moustaka et al. 2018). The high turbidity could also exacerbate non-consumptive fear effects caused by visual occlusion affecting prey detection, which has been shown to decrease rates of macroalgal removal (Bauman et al. 2019). At present, macroalgae removal still appears to be maintained with $S$. virgatus as the dominant macroalgal remover, but further degradation of reefs (and subsequent effects such as increased macroalgal cover and/or decreased fish biomass) could lead to a contraction of this function, as seen on other inshore reefs in Singapore with high macroalgal cover, low fish biomass, and low removal rates (Bauman et al. 2017). In addition, S. virgatus merely removes the leaves of Sargassum, leaving the holdfast intact, where Saragssum populations may regrow into macroalgal stands in the future (Loffler 2019). This is in contrast to species such as $K$. vaigiensis or N. unicornis on the GBR (Lefèvre and Bellwood 2011; Streit et al. 2015), that can remove whole thalli including holdfasts (Streit et al. 2015; Loffler and Hoey 2018) and therefore help control population sizes. Future studies should investigate whether the patterns observed in this study persist over a longer time frame, and if the herbivory rates in one year may influence the macroalgal biomass the following year. 


\section{Conclusion}

Temporal variation in macroalgal removal rates in Singapore is best explained by changes in S. ilicifolium condition while spatial variation is likely driven by local herbivore biomasses. It is clear that in Singapore, the process of macroalgal herbivory is largely reliant on a single species, $S$. virgatus, and there are indications that fluctuations in its population size can influence macroalgal herbivory rates. This reliance on S. virgatus, however, does not translate to dominance throughout the year as there is a short switch in feeding dominance to $S$. rivulatus when $S$. ilicifolium conditions are deteriorating. At present, the ecosystem function of macroalgae removal still appears to be maintained on the three reefs studied, but there are signs that further degradation of reefs (and subsequent effects such as loss of fish biomass) result in a reduction in this function and potentially lead to macroalgal dominance.

Acknowledgements We thank Jeffrey Low from the Singapore National Parks Board and members of the Experimental Marine Ecology Laboratory for their assistance in the field.

Author contributions This study was designed by AGB; the field work was carried out by AGB; the data analysis was conducted by JCLS; the paper was written by JCLS, PAT and AGB.

Funding This research is supported by the AXA Fellowship (154000-649-507), Wildlife Reserves Singapore Conservation Fund, and the National Research Foundation, Prime Minister's Office, Singapore under its Marine Science Research and Development Program (Award Nos. MSRDP-P03).

Data availability The datasets generated during and/or analysed during the current study are available from the corresponding author on reasonable request.

\section{Compliance with ethical standards}

Conflict of interest The authors declare that they have no conflict of interest or competing interests.

Ethic approval The authors declare that all applicable national and institutional guidelines for sampling, care and experimental use of organisms for the study have been followed and all necessary approvals were obtained, including permission from Singapore's National Parks Board (NP/PR15-009c).

Open Access This article is licensed under a Creative Commons Attribution 4.0 International License, which permits use, sharing, adaptation, distribution and reproduction in any medium or format, as long as you give appropriate credit to the original author(s) and the source, provide a link to the Creative Commons licence, and indicate if changes were made. The images or other third party material in this article are included in the article's Creative Commons licence, unless indicated otherwise in a credit line to the material. If material is not included in the article's Creative Commons licence and your intended use is not permitted by statutory regulation or exceeds the permitted use, you will need to obtain permission directly from the copyright holder. To view a copy of this licence, visit http://creativecommons.org/licenses/by/4.0/.

\section{References}

Barlow J, França F, Gardner TA, Hicks CC, Lennox GD, Berenguer E, Castello L, Economo EP, Ferreira J, Guénard B, Gontijo Leal C, Isaac V, Lees AC, Parr CL, Wilson SK, Young PJ, Graham NAJ (2018) The future of hyperdiverse tropical ecosystems. Nature 559:517-526

Barton K (2020). MuMIn: multi-model inference. R package version 1.43.17. https://CRAN.R-project.org/package=MuMIn. Accessed 1 July 2020

Bauman AG, Hoey AS, Dunshea G, Feary DA, Low J, Todd PA (2017) Macroalgal browsing on a heavily degraded, urbanized equatorial reef system. Sci Rep 7:1-8. https://doi.org/10.1038/s41598-01708873-3

Bauman AG, Seah JCL, Januchowski-Hartley FA, Hoey AS, Fong J, Todd PA (2019) Fear effects associated with predator presence and habitat structure interact to alter herbivory on coral reefs. Biol Lett. https://doi.org/10.1098/rsbl.2019.0409

Bellwood DR, Wainwright P (2001) Locomotion in labrid fishes: Implications for habitat use and cross-shelf biogeography on the Great Barrier Reef. Coral Reefs 20:139-150. https://doi.org/10.1007/ s003380100156

Bellwood DR, Hughes TP, Folke C, Nyström M (2004) Confronting the coral reef crisis. Nature 429:827-833

Bellwood DR, Streit RP, Brandl SJ, Tebbett SB (2019) The meaning of the term 'function' in ecology: a coral reef perspective. Funct Ecol 33:948-961. https://doi.org/10.1111/1365-2435.13265

Bennett S, Bellwood DR (2011) Latitudinal variation in macroalgal consumption by fishes on the Great Barrier Reef. Mar Ecol Prog Ser 426:241-252. https://doi.org/10.3354/meps09016

Brooks ME, Kristensen K, van Benthem KJ, Magnusson A, Berg CW, Nielsen A, Skaug HJ, Maechler M, Bolker BM (2017). glmmTMB balances speed and flexibility among packages for zero-inflated generalized linear mixed modeling. R J 9(2), 378-400. https://journal.r-project.org/archive/2017/RJ-2017066/index.html. Accessed 1 July 2020

Browne NK, Precht E, Last KS, Todd PA (2014) Photo-physiological costs associated with acute sediment stress events in three nearshore turbid water corals. Mar Ecol Prog Ser 502:129-143. https ://doi.org/10.3354/meps10714

Chow GSE, Chan YKS, Jain SS, Huang D (2019) Light limitation selects for depth generalists in urbanised reef coral communities. Mar Environ Res 147:101-112. https://doi.org/10.1016/j. marenvres.2019.04.010

Clements KD, German DP, Piché J, Tribollet A, Choat JH (2017) Integrating ecological roles and trophic diversification on coral reefs: multiple lines of evidence identify parrotfishes as microphages. Biol J Linn Soc 120:729-751

Cvitanovic C, Bellwood DR (2009) Local variation in herbivore feeding activity on an inshore reef of the Great Barrier Reef. Coral Reefs 28:127-133. https://doi.org/10.1007/s00338-008-0433-0

Diaz-Pulido G, McCook LJ (2003) Relative roles of herbivory and nutrients in the recruitment of coral-reef seaweeds. Ecology 84:2026-2033. https://doi.org/10.1890/01-3127

Fox RJ, Bellwood DR (2007) Quantifying herbivory across a coral reef depth gradient. Mar Ecol Prog Ser 339:49-59. https://doi. org/10.3354/meps339049

Fox RJ, Bellwood DR (2008) Direct versus indirect methods of quantifying herbivore grazing impact on a coral reef. Mar Biol 154:325-334. https://doi.org/10.1007/s00227-008-0927-x 
Graham NA, Bellwood DR, Cinner JE, Hughes TP, Norström AV, Nyström M (2013) Managing resilience to reverse phase shifts in coral reefs. Front Ecol Environ 11:541-548

Graham NAJ, Jennings S, MacNeil MA, Mouillot D, Wilson SK (2015) Predicting climate-driven regime shifts versus rebound potential in coral reefs. Nature 518:94-97. https://doi. org/10.1038/nature 14140

Guest JR, Todd PA, Goh E, Sivalonganathan BS, Reddy KP (2008) Can giant clam (Tridacna squamosa) populations be restored on Singapore's heavily impacted coral reefs? Aquat Conserv 18:570-579

Guest JR, Tun K, Low J, Vergés A, Marzinelli EM, Campbell AH, Bauman AG, Feary DA, Chou LM, Steinberg PD (2016) 27 years of benthic and coral community dynamics on turbid, highly urbanised reefs off Singapore. Sci Rep 6:1-10. https://doi.org/10.1038/ srep36260

Hartig F (2020). DHARMa: residual diagnostics for hierarchical (multi-level/mixed) regression models. $\mathrm{R}$ package version 0.3.1. https://CRAN.R-project.org/package=DHARMa. Accessed 1 July 2020

Heery EC, Hoeksema BW, Browne NK, Reimer JD, Ang PO, Huang D, Friess DA, Chou LM, Loke LHL, Saksena-Taylor P, Alsagoff N, Yeemin T, Sutthacheep M, Vo ST, Bos AR, Gumanao GS, Syed Hussein MA, Waheed Z, Lane DJW, Johan O, Kunzmann A, Jompa J, Suharsono TD, Bauman AG, Todd PA (2018) Urban coral reefs: Degradation and resilience of hard coral assemblages in coastal cities of East and Southeast Asia. Mar Pollut Bull 135:654-681. https://doi.org/10.1016/j.marpolbul.2018.07.041

Hoey AS (2010) Size matters: Macroalgal height influences the feeding response of coral reef herbivores. Mar Ecol Prog Ser 411:299302. https://doi.org/10.3354/meps08660

Hoey AS, Bellwood DR (2009) Limited functional redundancy in a high diversity system: Single species dominates key ecological process on coral reefs. Ecosystems 12:1316-1328. https://doi. org/10.1007/s10021-009-9291-z

Hoey AS, Bellwood DR (2010) Cross-shelf variation in browsing intensity on the Great Barrier Reef. Coral Reefs 29:499-508. https:// doi.org/10.1007/s00338-010-0605-6

Hoey AS, Bellwood DR (2011) Suppression of herbivory by macroalgal density: a critical feedback on coral reefs? Ecol Lett 14:267-273. https://doi.org/10.1111/j.1461-0248.2010.01581.x

Hoey AS, Brandl SJ, Bellwood DR (2013) Diet and cross-shelf distribution of rabbitfishes (f. Siganidae) on the northern Great Barrier Reef: Implications for ecosystem function. Coral Reefs 32:973-984. https ://doi.org/10.1007/s00338-013-1043-z

Hughes TP, Bellwood DR, Folke C, Steneck RS, Wilson J (2005) New paradigms for supporting the resilience of marine ecosystems. Trends Ecol Evol 20:380-386

Hughes TP, Rodrigues MJ, Bellwood DR, Ceccarelli D, Hoegh-Guldberg O, McCook L, Moltschaniwskyj N, Pratchett MS, Steneck RS, Willis B (2007) Phase shifts, herbivory, and the resilience of coral reefs to climate change. Curr Biol 17:360-365. https://doi.org/10.1016/j. cub.2006.12.049

Hughes TP, Graham NAJ, Jackson JBC, Mumby PJ, Steneck RS (2010) Rising to the challenge of sustaining coral reef resilience. Trends Ecol Evol 25:633-642

Hughes TP, Anderson KD, Connolly SR, Heron SF, Kerry JT, Lough JM, Baird AH, Baum JK, Berumen ML, Bridge TC, Claar DC, Eakin CM, Gilmour JP, Graham NAJ, Harrison H, Hobbs JPA, Hoey AS, Hoogenboom M, Lowe RJ, McCulloch MT, Pandolfi JM, Pratchett M, Schoepf V, Torda G, Wilson SK (2018) Spatial and temporal patterns of mass bleaching of corals in the Anthropocene. Science 359:80-83. https://doi.org/10.1126/science.aan8048

Junjie RK, Browne NK, Erftemeijer PLA, Todd PA (2014) Impacts of sediments on coral energetics: partitioning the effects of turbidity and settling particles. PLoS ONE 9:e107195. https://doi. org/10.1371/journal.pone.0107195

Kulbicki M, Guillemot N, Amand M (2005) A general approach to length-weight relationships for New Caledonian lagoon fishes. Cybium 29:235-252

Lai S, Loke LHL, Hilton MJ, Bouma TJ, Todd PA (2015) The effects of urbanisation on coastal habitats and the potential for ecological engineering: a Singapore case study. Ocean Coast Manag 103:78-85. https://doi.org/10.1016/j.ocecoaman.2014.11.006

Lefèvre CD, Bellwood DR (2010) Seasonality and dynamics in coral reef macroalgae: variation in condition and susceptibility to herbivory. Mar Biol 157:955-965. https://doi.org/10.1007/s00227-009-1376-x

Lefèvre CD, Bellwood DR (2011) Temporal variation in coral reef ecosystem processes: Herbivory of macroalgae by fishes. Mar Ecol Prog Ser 422:239-251. https://doi.org/10.3354/meps08916

Lenth R (2020). emmeans: estimated marginal means, aka least-squares means. R package version 1.4.7. https://CRAN.R-project.org/packa ge $=$ emmeans. Accessed 1 July 2020

Loffler Z (2019) The persistence of Sargassum communities on coral reefs: resilience and herbivory. $\mathrm{PhD}$ Thesis, James Cook University

Loffler Z, Hoey AS (2018) Canopy-forming macroalgal beds (Sargassum) on coral reefs are resilient to physical disturbance. J Ecol 106:11561164. https://doi.org/10.1111/1365-2745.12875

Loffler Z, Graba-Landry A, Kidgell JT, McClure EC, Pratchett MS, Hoey AS (2018) Holdfasts of Sargassum swartzii are resistant to herbivory and resilient to damage. Coral Reefs 37:1075-1084. https://doi. org/10.1007/s00338-018-01745-w

Low JKY, Fong J, Todd PA, Chou LM, Bauman AG (2019) Seasonal variation of Sargassum ilicifolium (Phaeophyceae) growth on equatorial coral reefs. J Phycol 55:289-296. https://doi.org/10.1111/jpy.12818

McCook LJ (1997) Effects of herbivory on zonation of Sargassum spp. within fringing reefs of the central Great Barrier Reef. Mar Biol 129:713-722. https://doi.org/10.1007/s002270050214

Moberg F, Folke C (1999) Ecological goods and services of coral reef ecosystems. Ecol Econ 29:215-233. https://doi.org/10.1016/S0921 -8009(99)00009-9

Moustaka M, Langlois TJ, McLean D, Bond T, Fisher R, Fearns P, Dorji P, Evans RD (2018) The effects of suspended sediment on coral reef fish assemblages and feeding guilds of north-west Australia. Coral Reefs 37:659-673. https://doi.org/10.1007/s00338-018-1690-1

Nanami A (2018) Spatial distributions, feeding ecologies, and behavioral interactions of four rabbitfish species (Siganus unimaculatus, S. virgatus, S. corallinus, and S. puellus). PeerJ. https://doi.org/10.7717/ peerj. 6145

Pinheiro J, Bates D, DebRoy S, Sarkar D, R Core Team (2020). nlme: linear and nonlinear mixed effects models. R package version 3.1-148, https://CRAN.R-project.org/package=nlme. Accessed 1 July 2020

Plass-Johnson JG, Ferse SCA, Jompa J, Wild C, Teichberg M (2015) Fish herbivory as key ecological function in a heavily degraded coral reef system. Limnol Oceanogr 60:1382-1391. https://doi.org/10.1002/ lno. 10105

Poquita-Du RC, Quek ZBR, Jain SS, Schmidt-Roach S, Tun K, Heery EC, Chou LM, Todd PA, Huang D (2019) Last species standing: loss of Pocilloporidae corals associated with coastal urbanization in a tropical city state. Mar Biodiv 49:1727-1741

Puk LD, Ferse SCA, Wild C (2016) Patterns and trends in coral reef macroalgae browsing: a review of browsing herbivorous fishes of the Indo-Pacific. Rev Fish Biol Fish 26:53-70. https://doi.org/10.1007/ s11160-015-9412-z

R Core Team (2020) R: A language and environment for statistical computing. R Foundation for statistical computing, Vienna. $\mathrm{R}$ version 4.0.0. http://www.R-project.org/. Accessed 1 July 2020

Richardson LE, Graham NAJ, Hoey AS (2020) Coral species composition drives key ecosystem function on coral reefs. Proc R Soc B Biol Sci. https://doi.org/10.1098/rspb.2019.2214 
Rivera M, Scrosati R (2006) Population dynamics of Sargassum lapazeanum (Fucales, Phaeophyta) from the Gulf of California, Mexico. Phycologia 45:178-189. https://doi.org/10.2216/05-47.1

Spalding MD, Ravilious C, Green EP (2001) World atlas of coral reefs. University of California Press, Prepared at the UNEP World Conservation Monitoring Centre

Streit RP, Hoey AS, Bellwood DR (2015) Feeding characteristics reveal functional distinctions among browsing herbivorous fishes on coral reefs. Coral Reefs 34:1037-1047. https://doi.org/10.1007/s0033 8-015-1322-y

Taira D, Poquita-Du RC, Toh TC, Ben TK, Ng CSL, Afiq-Rosli L, Chou LM, Song T (2018) Spatial variability of fish communities in a highly urbanised reef system. Urban Ecosyst 21:85-95. https://doi. org/10.1007/s11252-017-0691-0

Tebbett SB, Hoey AS, Depczynski M, Wismer S, Bellwood DR (2020) Macroalgae removal on coral reefs: realised ecosystem functions transcend biogeographic locations. Coral Reefs 39:203-214. https ://doi.org/10.1007/s00338-019-01874-w
Topor ZM, Rasher DB, Duffy JE, Brandl SJ (2019) Marine protected areas enhance coral reef functioning by promoting fish biodiversity. Conserv Lett 12:e12638

Wong LS, Chou LM (2004) Artificial reefs and marine re-stocking efforts in Singapore. In: proceedings of the 1st regional workshop on enhancing coastal resources: artificial reefs, stationary fishing gear design and construction and marine protected areas, $30 \mathrm{Sep}-$ tember-3 October 2003, Thailand. Training department, southeast asian fisheries development center, Samut Prakan, Thailand 81-86

Woodhead AJ, Hicks CC, Norström AV, Williams GJ, Graham NAJ (2019) Coral reef ecosystem services in the Anthropocene. Funct Ecol 33:1023-1034. https://doi.org/10.1111/1365-2435.13331

Publisher's Note Springer Nature remains neutral with regard to jurisdictional claims in published maps and institutional affiliations. 